\begin{tabular}{|l|l|l||}
\hline \multicolumn{2}{|c|}{ PublisherInfo } \\
\hline \hline PublisherName & $:$ & BioMed Central \\
\hline \hline PublisherLocation & $:$ & London \\
\hline \hline PublisherImprintName & $:$ & BioMed Central \\
\hline \hline
\end{tabular}

\title{
Watch your language!
}

\begin{tabular}{|l|l|l||}
\hline \multicolumn{2}{|c|}{ ArticleInfo } \\
\hline \hline ArticleID & $:$ & 4217 \\
\hline \hline ArticleDOI & $:$ & $10.1186 /$ gb-spotlight-20011005-01 \\
\hline \hline ArticleCitationID & $:$ & spotlight-20011005-01 \\
\hline \hline ArticleSequenceNumber & $:$ & 288 \\
\hline \hline ArticleCategory & $:$ & Research news \\
\hline \hline ArticleFirstPage & $:$ & 1 \\
\hline \hline ArticleLastPage & $:$ & 2 \\
\hline \hline & & RegistrationDate : 2001-10-05 \\
ArticleHistory & $:$ & OnlineDate \\
\hline \hline ArticleCopyright & $:$ & BioMed Central Ltd2001-10-05 \\
\hline \hline ArticleGrants & $:$ & \\
\hline \hline ArticleContext & $:$ & 130592211 \\
\hline \hline
\end{tabular}




\section{Jonathan B Weitzman}

Email: jonathanweitzman@hotmail.com

Several studies have suggested that there may be a genetic component to developmental disorders of speech and language, but no specific genes have been identified. In the October 4 Nature, Cecilia Lai and colleagues at the University of Oxford report mutations in a gene that correlates with such language disorders (Nature 2001, 413:519-522). Study of a family (called KE) with speech-language disorder led to the mapping of the SPCH1 locus on chromosome 7. Lai et al. performed fluorescence in-situ hybridisation (FISH) analysis to map a translocation breakpoint within this region in an unrelated patient with a similar disorder. This led them to the FOXP2 gene, which encodes a novel protein with a polyglutamine tract and a forkhead/winged-helix (FOX) DNA-binding domain. They also identified a point mutation (causing an arginine-to-histidine substitution) in the FOXP2 gene in the KE family that segregated with the language disorder. Mutations in other $F O X$ genes have previously been associated with a range of genetic disorders.

\section{References}

1. Genetic influence on language delay in two-year-old children

2. Nature, [http://www.nature.com]

3. University of Oxford, [http://www.ox.ac.uk]

4. Developmental verbal dyspraxia, [http://www.ncbi.nlm.nih.gov/entrez/dispomim.cgi?id=602081]

5. The SPCH1 region on human 7q31: genomic characterization of the critical interval and localization of translocations associated with speech and language disorder

This PDF file was created after publication. 